\title{
Balance and steadiness correction of the upright posture of patients having withstood an ischemic stroke with the help of stabilographic rehabilitation training equipment with biofeedback
}

\author{
Y. P. Bredikhina ${ }^{1,2}$, E.A. Baranova ${ }^{1}$, A.V. Kabachkova ${ }^{3}$, and Y.A. Gaevaya ${ }^{1}$ \\ ${ }^{1}$ National Research Tomsk Polytechnic University, Lenin Avenue, 30, Tomsk, 634050, Russia \\ ${ }^{2}$ Tomsk Research Institute of balneology and physiotherapy, st. Rosa Luxemburg 1, Tomsk, 634050, Russia \\ ${ }^{3}$ National Research Tomsk State University, Lenin Avenue, 36, Tomsk 634050, Russia
}

\begin{abstract}
The brain ischemic mortality rate in Russia occupies the third position. As a result, a recovery period after an ischemic stroke could undermine social and economic well-being of patients and their close relatives. One of the major consequences of a stroke includes the firm-motor defects. Their degree can be reduced with the help of rehabilitation measures intended to revive the motor function of paralyzed limbs and to train a patient to remain firm upright. A stabilographic rehabilitation training apparatus with biofeedback represents one of the variants of the posture training. This training in a playful way helps a patient to improve the balance and firmness indices of the upright position. This rehabilitation method improved considerably the patients' clinical and stabilographic indices of the balance and firmness function in comparison with the patients whose programmes did not include this method. A patient could sense better that he/she was standing on the both lower limbs. The sensitivity in the lower limbs was intensifying or reviving. According to the additional stabilographic control tests, the total scatter of the pressure centre and the scatter in the sagittal plane, the rate of the pressure centre movement were decreasing; Romberg coefficient became normal.
\end{abstract}

\section{Introduction}

The brain ischemic mortality rate in Russia occupies the third position $[1,2]$. In addition, the disability rate during the first year after an ischemic attack amounts to 80-85 $\%$ [2-4]. As a result, a recovery period after an ischemic stroke could undermine social and economic well-being of patients and their close relatives. One of the major consequences of a stroke includes the static-locomotory dysfunction [1, 5, 6]. It can be reduced using rehabilitation actions aimed at improvement of the motor function in paretic extremities and training patients keeping upright.

Reverse afferentation, going through various channels, is of great importance for a particular result, for a particular move, for achievement of the goal [2, 4, 7]. First of all, it occurs through afferents of muscles, joints, i.e. sensory mechanisms of the musculoskeletal system. Of no small important is the afferent impulses from such seemingly far from the motor system receptors as sight and hearing [2, 8]. The core of complex-coordination activities is a complex interaction of the vestibular analyzer and proprioceptors (dynamic analyzer), eyes and a nervous system. Thus, motion control depends on two main mechanisms. The first mechanism is the formation of a certain space-time structure of muscle activation corresponding to the given motor task and the initial position of the motor apparatus, which depends on innate connections and relationships, developed in the course of the previous motor experience $[4,5,6,9-12]$. The second mechanism involves correcting of the original structure of muscle activation. To characterize these two mechanisms the terminology of cybernetics is used: the first mechanism is called a program, the second correction is based on a feedback $[7,8]$.

One of the variants of postural recovery program includes the usage of the stabilographic rehabilitation training equipment with biofeedback $[2,3,6]$. Such training in a playful way helps patients to improve their balance and steadiness of the upright posture [3, 4]. Trainers promote formation of the skill of voluntary control of the position of a general centre of gravity and training of the balance function $[2,3,6,9,11]$. 


\section{Objective}

Study evaluates the possibilities of the stabilographic rehabilitation training devices with biofeedback for improving the upright posture steadiness of IHD patients.

\section{Materials and methods}

Study includes 50 people aged from 47 to 60 who have suffered from ischemic stroke in the vertebral basilar basin and were undergoing treatment in Tomsk Research Institute of balneotherapeutics and physical therapy. Patients were divided into two groups. The stabilographic rehabilitation training equipment with biofeedback was added to a course of treatment of the first group including 25 people (experimental group). The second group of 25 people received standard rehabilitation treatment (control group). Before and after the treatment all the patients were tested with the help of biofeedback of the computer stabiloanalyzer "Stabilan01-2" (produced in Russia by ZAO OKB RITM) in order to evaluate the balance function [6,7]. A stabilographic Romberg's test with closed and open eyes was used.

The course of treatment lasted 21 days. During the first 15 days the patients of the experimental group trained for 20 minutes at stabilographic rehabilitation training devices with biofeedback in addition to standard procedures. Two training programs were employed: "Balls Training" and "Blocks Training". Using those techniques patients learned to control their centre of gravity, which helped them to recuperate the feeling of steadiness.

A patient stands on a special platform. Fluctuations in the patient's center of pressure is displayed on the screen located at the eye level. The first task was to necessarily move patient's center of pressure without detachment of feet from the platform to the ball that reflects the center of pressure moved in an alternating cart. In the second task the patient pressure center is reflected on the screen cubes. Cubes needed to build a horizontal line. Feet should remain on the platform. In the classroom next to the patient there should always be a nurse, who is to prevent accidental patient's fall (Figure 1). Classes were held in the morning.

The research findings are represented as "average \pm error of mean" $\left(\mathrm{X}_{\mathrm{ave}} \pm \mathrm{m}\right)$. The Kolmogorov-Smirnov statistic test was used to assure normalcy of distribution. The reliability evaluation of the data are proved with the Mann-Whitney U test.

\section{Results and discussion}

No visible statistic differences between two groups were found during the stabilographic Romberg's test before the treatment. The patients of both groups generally were diagnosed with the gravity centre (COD) deviation in sagittal and frontal planes, accelerated COD displacement and the damaged balance function (table 1).
After the treatment the rate of COD dispersion at the frontal plane with eyes closed and open reliably reduced in the experimental group $(\mathrm{p}<0.05)$. In the control group, however, it was reduced only when the test was carried out with eyes closed $(\mathrm{p}<0.05$, table 1$)$. Moreover, Romberg's test with eyes closed showed that this rate was significantly lower in the experimental group than it was in the control group $(\mathrm{p}<0.05$, table 1$)$.

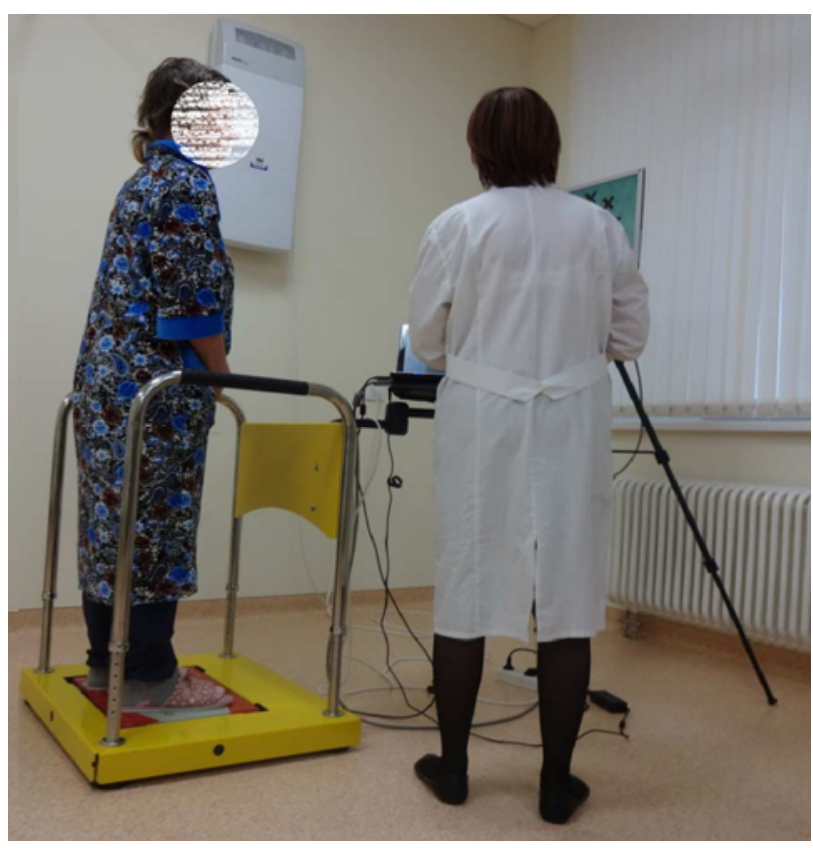

Fig. 1. Examination of the patient on the platform "Stabilographic"

In the control group the sagittal plane rate data after the treatment differed from the results of Romberg's test with open eyes before treatment $(p<0.05)$. In the experimental group the same rate (in both variants of Romberg's test) was also different from the ones before treatment, but the results of the groups were not the same $(\mathrm{p}<0.05$, table 1$)$.

The average dispersion of the experimental group patients was regressing while carrying out both types of Romberg's test $(\mathrm{p}<0.05)$, while in the control group it was reducing only when the test was carried out with eyes closed $(p<0.05$, table 1$)$. Romberg's test results with eyes open were the lowest in the experimental group $(\mathrm{p}<0.05$, table 1$)$.

Romberg's test with open eyes showed that in the experimental group the average displacement rate of the centre of pressure was noticeably diminished $(p<0.05)$, whereas in the control group the same effect was proved by Romberg's test with eyes closed ( $\mathrm{p}<0.05$, table 1$)$.

The rate of change of a force plate's surface diagram was reducing only in the experimental group $(p<0.05$, table 1).

The balance function was improving in both cases of Romberg's test in the first group $(p<0.05$, table 1$)$. In the second group this favorable effect was noticed only in case of the Romberg's test with open eyes $(p<0.05$, table 1). 
The average line rate was lower only in the experimental group after the treatment ( $\mathrm{p}<0.05$, table 1$)$.

Romberg index reduced in both groups but in the experimental group the result is rather substantial $(\mathrm{p}<0.05$, table 1$)$.

Introducing rehabilitation programs to the course of treatment, for the experimental and control group patients were recruited from 3 to 5 points (Table 2). After 15 days of treatment there was an improvement in this indicator by $11.9 \pm 0.9$ in the experimental group and by $6.7 \pm 0.7$ in the control group ( $<<0.05$, Table 2$)$.

The capturing time interval is reduced by half in patients of the experimental group and in the control there was a slight reduction ( $p<0,05$, Table 2$)$. Laying interval time after treatment has changed significantly in both groups ( $p>0,05$, Table 2$)$.

Indicators of the increased capture rate of $85 \%$ were in the experimental group and $43 \%$ - in the control group ( $>>0,05$, Table 2).

Laying speed indicators increased after treatment in the first group by $283 \%$ and increased slightly in the control group by $190 \%(p<0,05$, Table 2$)$.

In carrying out rehabilitation programs to the course of treatment, patients experimental and control group were recruited from 3 to 5 points (table 2). After 15 days of treatment there is an improvement in this indicator to $11.9 \pm 0.9$ in the experimental group and to $6.7 \pm 0.7$ in the control group ( $<<0.05$, table 2 ). The number dialed strings as after treatment was increased in both groups. But a more significant results were observed in patients of the experimental group (table 2).

Capturing time interval is reduced by half in patients of the experimental group and the control group slightly ( $<<0,05$, table 2 ). Laying interval time after treatment has changed significantly in both groups ( $p>0,05$, table 2).

Indicators of the increased capture rate of $85 \%$ were in the experimental group and $43 \%$ - in the control group ( $>0,05$, table 2).

Laying speed indicators increased after treatment in the first group by $283 \%$ and increased slightly in the control group by $190 \%(\mathrm{p}<0,05$, table 2$)$.

The most noticeable changes among stabilographic indicators rehabilitation simulators occurred among the high-speed performance. Patients using Biofeedback manipulated their pressure center and held an uncomfortable position easily.

According to the feedback of the patients from the experimental group, they felt more or less steadier standing on both feet and could practically or fully recuperate sensitivity recovery in lower limbs.

Thus, we can trace the improvement in patients' states after the treatment which results in development of the static balance sense - optimized functioning of the vestibular analyzer, the balance sense becomes more independent from the visual analyzer. It is shown in increasing dispersion and surface of COD displacement as well as in adequate changes in a speed rate. Also we can see the improvement in the balance function and Romberg index. At the same time, it should be noticed that the patients who, in addition to the standard treatment, exercised at stabilographic rehabilitation training devices equipped with biofeedback achieved better results. In the course of the game, the patients learnt to control their position of the general pressure center of their body at will training the balance function.

Table 1. Stabilographic figures demonstrating the results of Romberg's test before and after the treatment for patients suffered from ischemic stroke

\begin{tabular}{|c|c|c|c|c|}
\hline \multirow{4}{*}{$\begin{array}{l}\text { Performance } \\
\text { figures }\end{array}$} & \multicolumn{4}{|r|}{$\mathrm{X}_{\mathrm{ave}} \pm \mathrm{m}$} \\
\hline & \multicolumn{4}{|c|}{ Experimental group } \\
\hline & \multicolumn{2}{|c|}{ Before the treatment } & \multicolumn{2}{|c|}{ After the treatment } \\
\hline & $\begin{array}{l}\text { Open } \\
\text { eyes }\end{array}$ & $\begin{array}{l}\text { Closed } \\
\text { eyes }\end{array}$ & $\begin{array}{l}\text { Open } \\
\text { eyes }\end{array}$ & $\begin{array}{c}\text { Closed } \\
\text { eyes }\end{array}$ \\
\hline $\begin{array}{c}\text { Frontal } \\
\text { plane COD } \\
\text { dispersion, } \\
\mathrm{mm} \\
\end{array}$ & $\begin{array}{l}5.48 \pm \\
0.08 \#\end{array}$ & $8.9 \pm 0.9 \#$ & $4.05 \pm 0.3$ & $5.7 \pm 0.6^{*}$ \\
\hline $\begin{array}{c}\text { Sugittal } \\
\text { plane COD } \\
\text { dispersion, } \\
\mathrm{mm} \\
\end{array}$ & $\begin{array}{c}6.97 \pm \\
0.6 \#\end{array}$ & $\begin{array}{c}6.37 \pm 0.6 \\
\#\end{array}$ & $4.5 \pm 0.5 *$ & $\begin{array}{c}4.14 \pm 0.3 \\
*\end{array}$ \\
\hline $\begin{array}{c}\text { Average } \\
\text { dispersion, } \\
\text { mm }\end{array}$ & $\begin{array}{c}6.3 \pm 0.7 \\
\#\end{array}$ & $7.6 \pm 0.6 \#$ & $4.3 \pm 0.4^{*}$ & $4.92 \pm 0.3$ \\
\hline $\begin{array}{l}\text { Average } \\
\text { displacement } \\
\text { rate of the } \\
\text { centre of } \\
\text { pressure, } \\
\mathrm{mm} / \mathrm{sec}\end{array}$ & $\begin{array}{c}15.3 \pm \\
0.8 \#\end{array}$ & $16.9 \pm 1.1$ & $\begin{array}{l}10.6 \pm 0.6 \\
*\end{array}$ & $13.2 \pm 0.9$ \\
\hline $\begin{array}{c}\text { Rate of } \\
\text { change of a } \\
\text { force plate's } \\
\text { surface } \\
\text { diagram, } \\
\mathrm{mm}^{2} / \mathrm{sec}\end{array}$ & $\begin{array}{c}17.4 \pm 1 \\
4 \#\end{array}$ & $\begin{array}{c}34.8 \pm 2.5 \\
\#\end{array}$ & $\begin{array}{c}11.7 \pm 0.9 \\
*\end{array}$ & $\begin{array}{c}21.9 \pm 1.3 \\
*\end{array}$ \\
\hline $\begin{array}{c}\text { Balance } \\
\text { function, } \%\end{array}$ & $\begin{array}{c}48.1 \pm 5 . \\
1 \#\end{array}$ & $\begin{array}{c}34.7 \pm 2.9 \\
\#\end{array}$ & $\begin{array}{c}75.1 \pm 8.2 \\
*\end{array}$ & $\begin{array}{c}51.9 \pm 3.9 \\
*\end{array}$ \\
\hline $\begin{array}{l}\text { Average line } \\
\text { rate, } \mathrm{mm} / \mathrm{sec}\end{array}$ & $\begin{array}{c}6.7 \pm 0.7 \\
\#\end{array}$ & $9.3 \pm 0.7 \#$ & $4.4 \pm 0.3 *$ & $7.1 \pm 0.4$ \\
\hline $\begin{array}{l}\text { Romberg } \\
\text { index }\end{array}$ & \multicolumn{2}{|c|}{$337 \pm 27 \#$} & \multicolumn{2}{|c|}{$242.2 \pm 19 *$} \\
\hline \multirow{3}{*}{$\begin{array}{l}\text { Performance } \\
\text { figures }\end{array}$} & \multicolumn{4}{|c|}{ Experimental group } \\
\hline & \multicolumn{2}{|c|}{ Before the treatment } & \multicolumn{2}{|c|}{ After the treatment } \\
\hline & $\begin{array}{l}\text { Open } \\
\text { eyes }\end{array}$ & $\begin{array}{l}\text { Closed } \\
\text { eyes }\end{array}$ & $\begin{array}{l}\text { Open } \\
\text { eyes }\end{array}$ & $\begin{array}{l}\text { Closed } \\
\text { eyes }\end{array}$ \\
\hline $\begin{array}{c}\text { Frontal } \\
\text { plane COD } \\
\text { dispersion, } \\
\mathrm{mm} \\
\end{array}$ & $\begin{array}{c}5.61 \pm 0 . \\
7\end{array}$ & $\begin{array}{c}8.75 \pm 0.6 \\
\#\end{array}$ & $4.21 \pm 0.3$ & $6.37 \pm 0.7$ \\
\hline $\begin{array}{c}\text { Sugittal } \\
\text { plane COD } \\
\text { dispersion, } \\
\text { mm }\end{array}$ & $\begin{array}{c}7.01 \pm 0 . \\
8 \#\end{array}$ & $6.5 \pm 0.6$ & $5.4 \pm 0.4$ & $4.65 \pm 0.3$ \\
\hline $\begin{array}{c}\text { Average } \\
\text { dispersion, } \\
\mathrm{mm}\end{array}$ & $\begin{array}{c}6.32 \pm 0 \\
8\end{array}$ & $\begin{array}{c}7.63 \pm 0.9 \\
\#\end{array}$ & $4.8 \pm 0.4$ & $5.5 \pm 0.4$ \\
\hline
\end{tabular}




\begin{tabular}{|c|c|c|c|c|}
\hline $\begin{array}{c}\text { Average } \\
\text { displacement } \\
\text { rate of the } \\
\text { centre of } \\
\text { pressure, } \\
\mathrm{mm} / \mathrm{sec}\end{array}$ & $\begin{array}{c}15.7 \pm 0 . \\
9\end{array}$ & $\begin{array}{c}17.1 \pm 1.4 \\
\#\end{array}$ & $13.8 \pm 1.1$ & $12.1 \pm 0.9$ \\
\hline $\begin{array}{c}\text { Rate of } \\
\text { change of a } \\
\text { force plate's } \\
\text { surface } \\
\text { diagram, } \\
\text { mm } / \mathrm{sec}\end{array}$ & $\begin{array}{c}17.2 \pm 1 . \\
4\end{array}$ & $32.9 \pm 2.1$ & $14.9 \pm 0.9$ & $25.7 \pm 2.3$ \\
\hline $\begin{array}{c}\text { Balance } \\
\text { function, \% }\end{array}$ & $\begin{array}{c}47.85 \pm 5 \\
\#\end{array}$ & $35.2 \pm 2.2$ & $61.3 \pm 5.1$ & $45.6 \pm 3.8$ \\
\hline $\begin{array}{c}\text { Average line } \\
\text { rate, mm/sec }\end{array}$ & $\begin{array}{c}6.55 \pm 0 . \\
7\end{array}$ & $8.4 \pm 0.7$ & $5.3 \pm 0.2$ & $6.9 \pm 0.6$ \\
\hline $\begin{array}{c}\text { Romberg } \\
\text { index }\end{array}$ & \multicolumn{2}{|c|}{$334.3 \pm 29 \#$} & \multicolumn{2}{|c|}{$285.7 \pm 16$} \\
\hline
\end{tabular}

$*$ - significance of differences from the control group, $\mathrm{p}<0.05$;

\# - significance of differences inside the group before and after the treatment, $\mathrm{p}<0.05$.

Table 2. Stabilographic figures demonstrating the results of rehabilitation programs before and after the treatment for patients suffered from ischemic stroke

\begin{tabular}{|c|c|c|}
\hline \multirow[b]{3}{*}{ Performance figures } & \multicolumn{2}{|r|}{$\mathrm{X}_{\mathrm{ave}} \pm \mathrm{m}$} \\
\hline & \multicolumn{2}{|c|}{ Experimental group } \\
\hline & $\begin{array}{l}\text { Before the } \\
\text { treatment }\end{array}$ & $\begin{array}{l}\text { After the } \\
\text { treatment }\end{array}$ \\
\hline Spectacles & $4.1 \pm 0.4$ & $11.9 \pm 0.9^{*}$ \\
\hline Lines & $0.9 \pm 0.09$ & $4.5 \pm 0.5$ \\
\hline Capture interval, sec & $7.8 \pm 0.9$ & $3.5 \pm 0.4^{*}$ \\
\hline Stacking interval, sec & $14,2 \pm 0.9 *$ & $7.3 \pm 0.9 *$ \\
\hline $\begin{array}{l}\text { Capture rate, } \mathrm{mm} / \\
\mathrm{sec}\end{array}$ & $48.2 \pm 3.2 \#$ & $89.3 \pm 8.3$ \\
\hline $\begin{array}{l}\text { Laying speed, mm / } \\
\text { sec }\end{array}$ & $20.4 \pm 1.1 * \#$ & $78.3 \pm 7.4^{*}$ \\
\hline \multirow{2}{*}{ Performance figures } & \multicolumn{2}{|c|}{ Experimental group } \\
\hline & $\begin{array}{l}\text { Before the } \\
\text { treatment }\end{array}$ & $\begin{array}{l}\text { After the } \\
\text { treatment }\end{array}$ \\
\hline Spectacles & $3.95 \pm 0.8$ & $6.7 \pm 0.7$ \\
\hline Lines & $0.95 \pm 0.09$ & $2.4 \pm 0.5$ \\
\hline Capture interval, sec & $7.3 \pm 0.8$ & $5.7 \pm 0,6$ \\
\hline Stacking interval, sec & $13,7 \pm 1.2$ & $10.8 \pm 1.3$ \\
\hline $\begin{array}{l}\text { Capture rate, } \mathrm{mm} / \\
\mathrm{sec}\end{array}$ & $46.7 \pm 0.5$ & $67.2 \pm 10$ \\
\hline $\begin{array}{l}\text { Laying speed, mm / } \\
\text { sec }\end{array}$ & $19.9 \pm 0.9 \#$ & $58.6 \pm 6.3$ \\
\hline
\end{tabular}

* - significance of differences with the control group, $\mathrm{p}<0.05$;

\# - significance of differences inside the group before and after the treatment, $\mathrm{p}<0.05$.

\section{Conclusion}

The conducted research helped to evaluate the positive effect that stabilographic rehabilitation training devices equipped with biofeedback have on patients suffered from ischemic stroke while they are trying to improve the upright posture stability. Patients becoming more stable on both feet, and could practically or fully recuperate sensitivity recovery in lower limbs. In the course of the game, the patients learnt to control position of the general pressure center of their body at will training the balance function. There was a proceeding increase in the degree of freedom of movement of the upper and lower extremities, proceeding improvement of their psychological state, proceeding improvement in social and economic well-being of patients and their close relatives. Owing to rehabilitation actions aimed at improvement of motor function in paretic extremities and training patients in holding the upright position, there was a noticeable reduction of the disability rate during the first year after an ischemic attack amounts.

\section{References}

1. P. Artuhov, Zdravoohranenie, 12, (2011)

2. M.E Khallaf, A.M. Gabr, E.E. Faved, Neurol. Res. Int., 9, (2014)

3. T.R. Bischof, D.J. Kurz, Praxis, 104, 841-846 (2015)

4. J. Faulkner, G. McGonigal, B. Woolley, Clin. Rehabilit, 29, 783-784 (2015)

5. S.A. Moore, K. Hallsworth, D.G. Jakovljevic, Neur. Rehabilit. Neur. Rep, 29, 623-635 (2015)

6. S.A., Billinger, R. Arena, J. Bernhardt, Stroke, 45, 8 (2014)

7. M. Kristofferzon, R. Löfmark, M. Carlsson, J Clin. Nurs., 16, 2 (2007)

8. O.V. Cubreac, S.S. Grokhovsky, Practical stabilometry. Static motor-cognitive tests with biofeedback to support reaction (M.: Mask, 2012)

9. L.V. Kapilevich, F.A. Guzhov, Y.P. Bredikhina, A.A. Il'in, TaPPC, 12, 7 (2014).

10. D. Scrutinio, V. Monitillo, P. Guida, Stroke, 46, 10 (2015)

11. E.A. Baranova, V.I., Andreev, L.V. Kapilevich, Mod. Probl. Syst. Regul. Physiol. Funct.: 4th Intern. Interdiscipl. Conf, 55, (2015) 